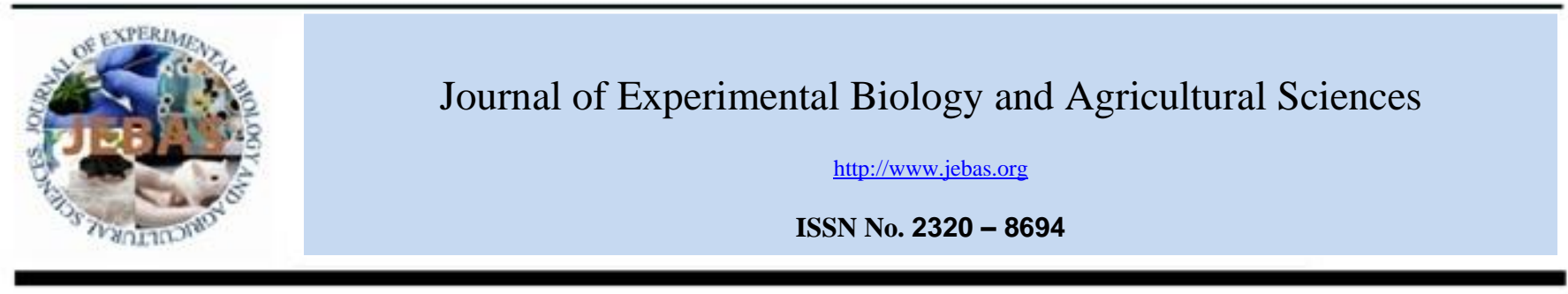

\title{
COMPLEMENTARY AND ALTERNATIVE MEDICINES AMONG RESIDENTS IN UPLAND CAVITE, PHILIPPINES: THEIR KNOWLEDGE, PATTERNS OF USE AND ATTITUDES
}

\author{
Johnny A Ching ${ }^{1,2, *}$, Rodante G Flores ${ }^{2,3}$ and Maxima J Acelajado ${ }^{2}$ \\ ${ }^{1}$ Biological Sciences Department, College of Science and Computer Studies, De La Salle University-Dasmariñas, Cavite, Philippines \\ ${ }^{2}$ Graduate Studies Department, College of Science and Computer Studies, De La Salle University-Dasmariñas, Cavite, Philippines \\ ${ }^{3}$ PATTS College of Aeronautics, Paranaque, Metro Manila, Philippines
}

Received - February 03, 2016; Revision - February 17, 2016; Accepted - March 30, 2016

Available Online - April 25, 2016

DOI: http://dx.doi.org/10.18006/2016.4(2).133.141

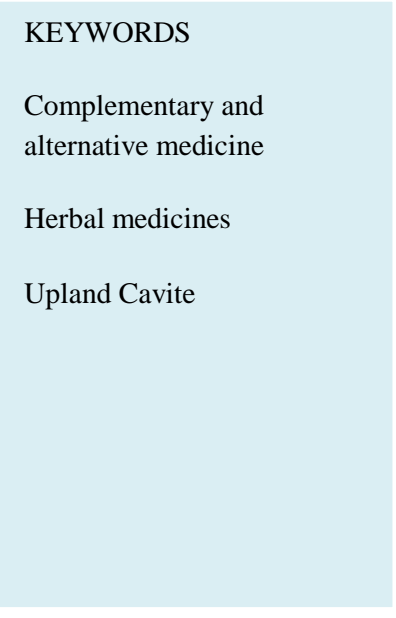

\begin{abstract}
The study was aimed to determining the knowledge, patterns of use, and attitude towards the use of complementary and alternative medicines $(C A M)$ by herbalists $(n=38)$ and lay people $(n=582)$ from the municipalities of Indang, Maragondon, Amadeo, Magallanes, and Alfonso and the city of Tagaytay, all located in the upland portion of the province of Cavite. Data pertinent to the afore-said aims were gathered through questionnaires and focus group discussions. Nine forms of CAM were documented as used by the interviewees. Leaf extract (decoction) and traditional massage (hilot)was the most prevalent types of CAM across all studied areas, contributing $71 \%(n=440)$ and $54 \%(n=335)$, respectively. Furthermore, their widespread utilization was mainly due to the recommendations from family members $(31 \%, \mathrm{n}=192)$ and doctors $(35 \%, \mathrm{n}=217)$. Amongst the various ailments associated with the use of CAM, common colds $(70 \%, n=434)$, cough $(69 \%, n=428)$, and fever $(61 \%, n=378)$ were the most treated. Overall, a generally positive attitude towards the use of all forms of CAM recorded in this study was shown by most participants in all the surveyed municipalities/city. Therefore, present study concludes that CAM plays a major health care role amongst the interviewees.
\end{abstract}

* Corresponding author

E-mail: jaching@dlsud.edu.ph (Johnny A Ching)

Peer review under responsibility of Journal of Experimental Biology and Agricultural Sciences.

Production and Hosting by Horizon Publisher India [HPI] (http://www.horizonpublisherindia.in/).

All rights reserved.
All the article published by Journal of Experimental Biology and Agricultural Sciences is licensed under a Creative Commons Attribution-NonCommercial 4.0 International License Based on a work at www.jebas.org.

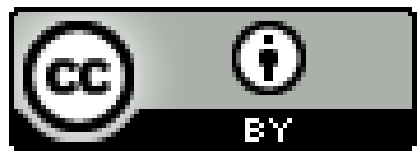




\section{Introduction}

The practice of complementary and alternative medicines (CAM) is very common in many countries of the world, including where modern biomedical healthcare is predominant and readily available (Shaikh et al., 2008). CAM is a group of diverse medical and healthcare systems, therapies, and products that are not presently considered to be part of modern medicine. A therapy is generally considered to be as complementary when it is used in combination with conventional treatments while it is considered as alternative when it is used in place of the modern treatment (Koh et al., 2004). Recognizing that there can be some overlapping amongst the therapies, the National Center for Complementary and Integrative Health (NCCIH) (2012)formerly the National Center for Complementary and Alternative Medicine (NCCAM) of the US Department of Health and Human Services categorized CAM practices into two subgroups: natural products or mind and body practices. Natural products include use of a variety of biologically-based products such as herbs or botanicals, vitamins and minerals, and probiotics. These products are widely-marketed, readily available as dietary supplements. Mind and body practices includes a large and diverse group of practices or procedures usually administered by a trained practitioner such as massage therapy, acupuncture, yoga, qi gong, and meditation.

Literature-based evidences exist indicating that the practice of CAM is common in most developing countries including India (Singh et al., 2004; Jadhav et al., 2011; Roy et al., 2015), Malaysia (Lee et al., 2007; Sivadasan et al., 2014; Silvanathan \& Low 2015), Africa (Matheka \& Demaio 2013; McFarlane, 2015), and Mexico (Valenzuela-Antelo et al., 2011; Marshik et al., 2016). This is therefore suggests that CAM is an important aspect of public health care in these countries. Studies also highlighted that there is an increasing prevalence of CAM use among Western physicians practicing in developed countries (Bensoussan et al., 2004; Koh et al., 2004; Wolf et al., 2006; Stange et al., 2008). The apparent reversal of trend from modern to traditional medicine is partly attributed to the multifaceted factors including the fact that synthetic drugs have always shown adverse reactions and other undesirable side effects (Erasto\& Majinda, 2011).

In addition, the high cost of administering modern drugs, which is beyond the reach of many people in the low income group and of those living in the rural areas is also responsible for this trend (Erasto et al., 2005). Regardless of the earlier eluded studies reporting on the significant of CAM in various countries, there are still dearth of information relating to the utilization of this therapy, particularly the knowledge, patterns of use, and attitude towards its use by residents in the upland portions of the province of Cavite, Philippines. The present study was therefore initiated as an attempt to contribute towards this gap in knowledge.

\section{Materials and Methods}

2.1 Study area and data collection

The study was carried out in Indang, Maragondon, Amadeo, Magallanes, Alfonso and Tagaytay city located in the upland portion of the province of Cavite. A total of 620 respondents ( 38 herbalists and 582 lay people/users of CAM), average of 100 participants from each municipality and city, were purposely selected.

Data were collected using a pre-tested questionnaires and focus group discussions (Erasto et al., 2005). The protocol was approved by the Research Ethics Committee under the University Research Office (URO) of De La Salle UniversityDasmariñas, and informed consent was obtained from all the respondents, who were willing to take part in the study, prior to the data collection. Self-administered questionnaires and group discussion as adapted from previous studies (Furnham, 2000; Xue et al., 2007; Shaikh et al., 2008) but with a sight modification was aligned to gather information relating to the respondents' knowledge, patterns of use, and attitude towards the use of CAM.

The questionnaires were distributed to each of the respondents. Those who needed assistance in terms of understanding and filling-up the questionnaire were assisted by their family relatives. The completed questionnaires were retrieved by the researchers three weeks after the distribution, and subsequently, a face-to-face interview and focus group discussion with respondents was conducted to gather other relevant information that might not have captured by respondents.

\subsection{Data analysis}

Comparison technique and descriptive statistics such as percentage/frequencies was used to analyze certain data collected across all the studied municipalities/city. Furthermore, Likert scale was used to evaluate the attitude of the respondents towards CAM, with 5 representing very strong and 1 representing very weak responses.

\section{Results and Discussion}

A total of 620 respondents with ages ranging from 16 to 68 years old from the selected city and municipalities in upland Cavite disclosed that they utilize CAM, thus suggesting that this sort of therapy is common amongst all age brackets in the study areas. There was almost an equal ratio between male $(48 \% ; \mathrm{n}=300)$ and female $(52 \%, \mathrm{n}=320)$ respondents and most of them attained only up to secondary education. This finding therefore, buttresses the common knowledge that most of the users of CAM obtained lower educational qualifications. 
Table 1 Different form of complementary and alternative medicines used by residents (in percent) of selected city and municipalities representing upland Cavite.

\begin{tabular}{|c|c|c|c|c|c|c|}
\hline \multirow[t]{3}{*}{ Forms of CAM } & \multicolumn{6}{|c|}{ Municipalities/City } \\
\hline & $\begin{array}{l}0 \\
\mathscr{0} \\
\stackrel{0}{0} \\
\stackrel{0}{Z}\end{array}$ & 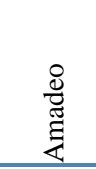 & $\begin{array}{l}\text { Do } \\
\text { E్ } \\
\text { E }\end{array}$ & 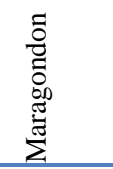 & $\frac{N}{\frac{N}{E}}$ & 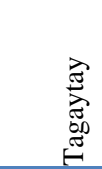 \\
\hline & $\mathrm{n}=116$ & $\mathrm{n}=98$ & $\mathrm{n}=100$ & $\mathrm{n}=100$ & $\mathrm{n}=94$ & $\mathrm{n}=112$ \\
\hline Leaf extract/decoction & 64 & 78 & 78 & 81 & 68 & 56 \\
\hline Traditional massage & 47 & 68 & 68 & 45 & 48 & 46 \\
\hline Herbal tablets & 33 & 8 & 55 & 24 & 7 & 11 \\
\hline Rituals & - & 43 & - & 29 & 6 & 1 \\
\hline Plastering of leaves & 3 & 4 & - & 22 & 2 & 1 \\
\hline Western massage (spa) & - & - & - & 11 & - & - \\
\hline Pravers and murmuring & - & - & - & 13 & - & - \\
\hline Yoga and meditation & - & - & - & 5 & - & - \\
\hline Oigong & - & - & - & 6 & - & - \\
\hline
\end{tabular}

3.1 Forms of CAM used by the Respondents

Table 1 shows the various forms of CAM being used by the respondents from the upland areas of the province of Cavite. Drinking of decoction or leaf extracts of medicinal plants and traditional massage are the two most popular forms of CAM in all sampling areas. Other forms of CAM being used to some extent include drinking herbal tablets, performing different rituals and plastering of leaves.

Respondents from Maragondon showed more varied forms of CAM compared to other places in the upland area, such as going to modern spa and practicing yoga and meditation. This might be due attributed to the diversity of medical knowledge possessed by inhabitants from Maragondon as opposed to other municipalities. The opposite of this might be true amongst the participants from Indang who reported the least forms of CAM. On one hand the least noted types of CAM amid participants to some extent indicate that they rely on medicinal plants. This is ascribed to the fact that most sorts of CAM they noted are plant derives. On the other hand high preferences of herbal medicine in a form of tablet by interviewees from Indang compared to those residing in other studied areas, is suggestive of the respondents' preference for readily available medicines in pack rather than for raw herbal medicines, which requires preparation. Figure 1 shows an over-all graphic comparison of the most common forms of CAM used by the residents of upland Cavite. It is clear from the graph that drinking of leaf extract or decoction and traditional massage represent more than $70 \%$ of the combined responses in almost all surveyed areas. This finding is somewhat in line that previously reported by Salibay et al. (2007) and Arsenio et al. (2011) in the Philippines. Furthermore, Shaikh et al. (2008) who also conducted a similar study in Pakistan reported comparable finding to present study. On contrary a study carried out in Australia reported acupuncture as predominant CAM (Bensoussan et al., 2004). This disparity might be attributed to the variation in knowledge or preferred form of CAM amongst the Australians and Filipinos.

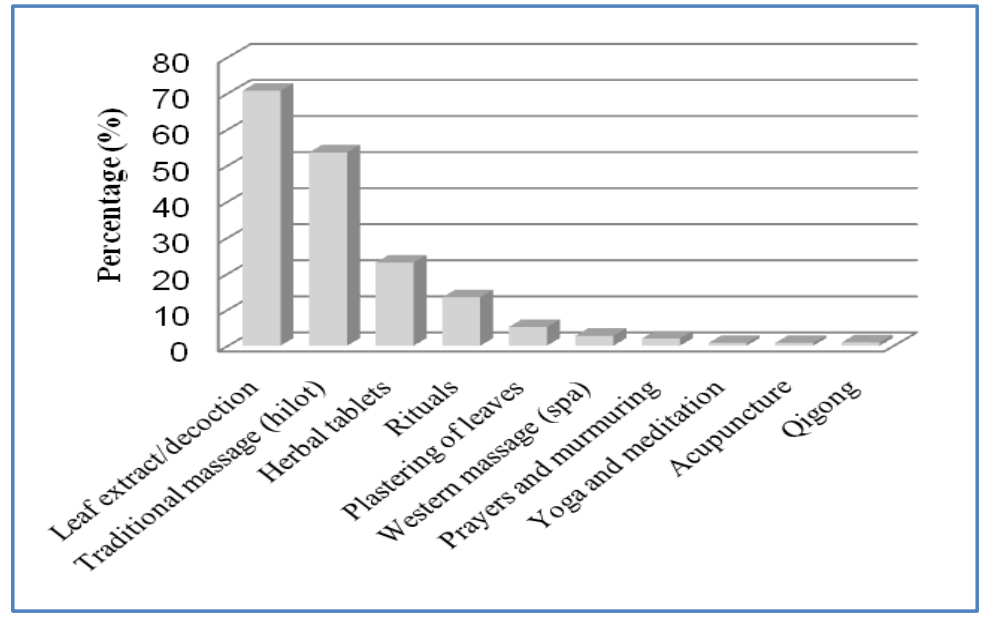

Figure 1 Over-all forms of CAM used by the residents of upland Cavite. 
Table 2 Reasons given by the residents (in percent) for using CAM of selected city and municipalities representing upland Cavite.

\begin{tabular}{|c|c|c|c|c|c|c|}
\hline \multirow[t]{3}{*}{ Reasons for using CAM } & \multicolumn{6}{|c|}{ Municipalities/City } \\
\hline & 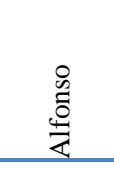 & 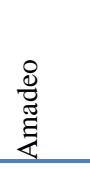 & 呚 & 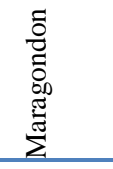 & $\frac{N}{\frac{N}{0}}$ & 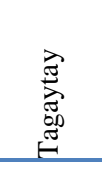 \\
\hline & $\mathrm{n}=116$ & $\mathrm{n}=98$ & $\mathrm{n}=100$ & $\mathrm{n}=100$ & $\mathrm{n}=94$ & $\mathrm{n}=112$ \\
\hline Recommended by medical practitioner & 21 & 59 & 44 & - & 23 & 42 \\
\hline Recommended by friends or family & 45 & 20 & 61 & 41 & 1 & 13 \\
\hline To treat health problems & 28 & 27 & 21 & 22 & 33 & 16 \\
\hline Natural and therefore safer & 1 & 8 & - & 38 & 5 & 1 \\
\hline For maintenance of general health & 3 & 3 & 2 & 5 & 8 & 1 \\
\hline Dissatisfaction with conventional medicine & - & 3 & - & 6 & - & - \\
\hline To relieve stress & - & 4 & - & 8 & - & - \\
\hline
\end{tabular}

However, the least utilization of other forms of CAM in this study was expected. For instance, limited use of Western massage might be due to its high cost which is way beyond the reach of many participants in this study. Yoga and meditation might be least utilised due to the fact that its time consuming. Surprisingly, prayer and murmuring was expected to be featured amongst the top used CAM, as most of the Filipinos are religious.

\subsection{Reasons for using CAM}

Based from the interview and survey conducted, there were eight primary reasons why the residents in the upland areas of Cavite tend to practice CAM. Table 2 below shows the various reasons given by the respondents. Six major reasons were identified by the respondents why they prefer to use CAM (Table 2). Respondents from the municipalities of Alfonso,
Indang, and Maragondon were persuaded by family members for using different forms of CAM. Given that most of the respondent are old people, this finding suggest the practice of CAM amid participants in this municipalities is an old tradition passed from one generation to another. On contrary, people questioned in the Tagaytay City and municipality of Amadeo use CAM as ordered by doctors, thus suggesting that most of inhabitants in this areas reliant on western health care services for their well-being. The results obtained from Mendez showed that participants use CAM from probable positive past experiences. Overall the various reasons as outlined in Table 2, put forth by participants for utilizing CAM is obviously associated with either tradition or trust that they have in the person who recommended them. The over-all reasons for using CAM by the residents of upland Cavite are graphically presented in figure 2.

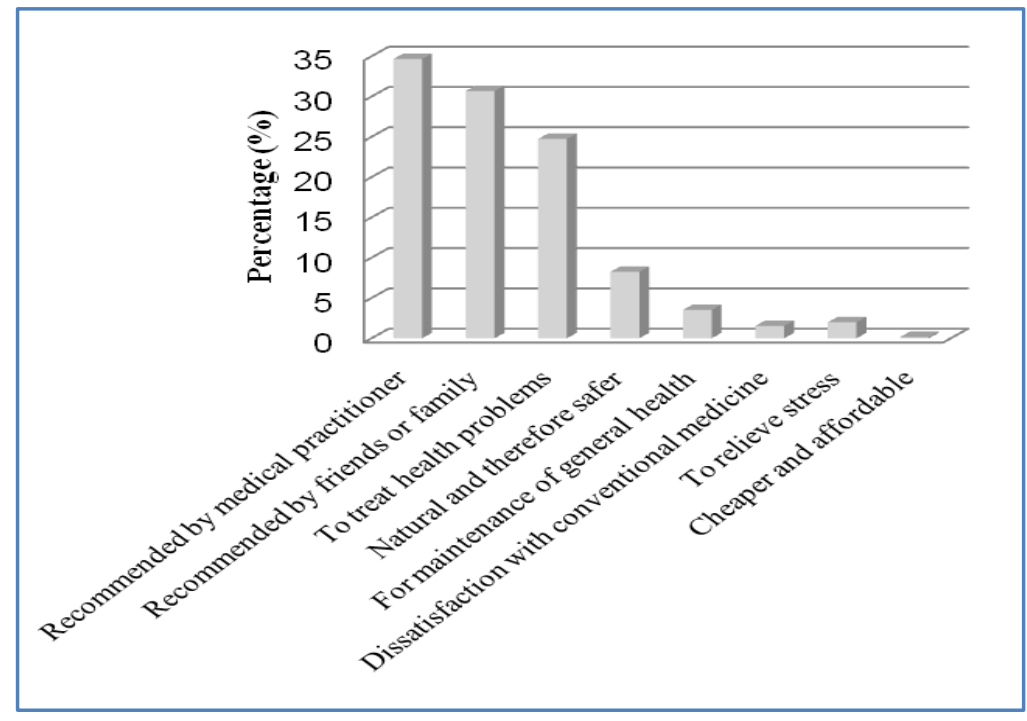

Figure 2 Over-all reasons for using CAM by the residents of upland Cavite. 
Table 3 Ailments associated with the usage of CAM as given by the residents (in percent) of selected city and municipalities representing upland Cavite.

\begin{tabular}{|c|c|c|c|c|c|c|}
\hline \multirow{3}{*}{$\begin{array}{l}\text { Disease associated for using } \\
\text { traditional medicine }\end{array}$} & \multicolumn{6}{|c|}{ Municipalities/City } \\
\hline & $\begin{array}{l}0 \\
0 \\
0 \\
\end{array}$ & 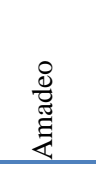 & 点 & 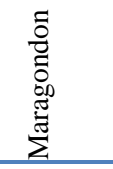 & $\frac{N}{\mathbb{U}}$ & 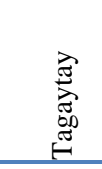 \\
\hline & $\mathrm{n}=116$ & $\mathrm{n}=98$ & $\mathrm{n}=100$ & $\mathrm{n}=100$ & $\mathrm{n}=94$ & $\mathrm{n}=112$ \\
\hline Common colds & 64 & 78 & 77 & 91 & 60 & 49 \\
\hline Cough & 64 & 73 & 77 & 89 & 61 & 50 \\
\hline Fever & 64 & 71 & 77 & 59 & 50 & 42 \\
\hline Flu & 10 & 41 & 8 & 26 & 2 & 5 \\
\hline High blood pressure & 4 & 9 & 13 & 2 & 2 & 4 \\
\hline Muscle pains & 3 & 12 & 7 & 4 & 9 & 4 \\
\hline Diabetes & 2 & 9 & 2 & - & 9 & 4 \\
\hline Abdominal pains & - & 3 & 3 & 12 & - & 1 \\
\hline Asthma & 2 & - & 4 & - & 3 & - \\
\hline Skin diseases & 1 & 1 & 2 & 1 & 2 & 1 \\
\hline UTI & 1 & 5 & - & - & 1 & - \\
\hline Diarrhea & 1 & - & 1 & - & - & - \\
\hline
\end{tabular}

One of the reasons given by respondents in this study for practicing CAM, particularly leaf extract/decoction, traditional massage and herbal tablets is due to both the abundant and availability of plants resource, a similar finding which is common among Filipino families. This fact is to some extent supported by more than 40 medicinal plant species (Appendix 1) reported by participants the across all the studied areas. Other pressing reasons for the use of herbal medicine, reported in this study which are comparable to previous studies (Furnham, 2000; Kuo et al., 2004; Salibay et al., 2009) include their high potency and safeness as compared to synthetic medicines.
3.3 Ailments Associated with usage of CAM

The top three ailments identified by the respondents associated with CAM were common colds, cough, and fever. This finding are in harmony with those previously noted by Arsenio et al. (2011) in Philippines, and Shaikh et al. (2008) in Pakistan, both reporting colds, cough and fever are being amongst the top ailments treated with CAM. On contrary, Strange et al. (2008) reported hypertension and cancer as highly treated disorders in Germany. This might be an indication that these diseases are prevalent in Germany.

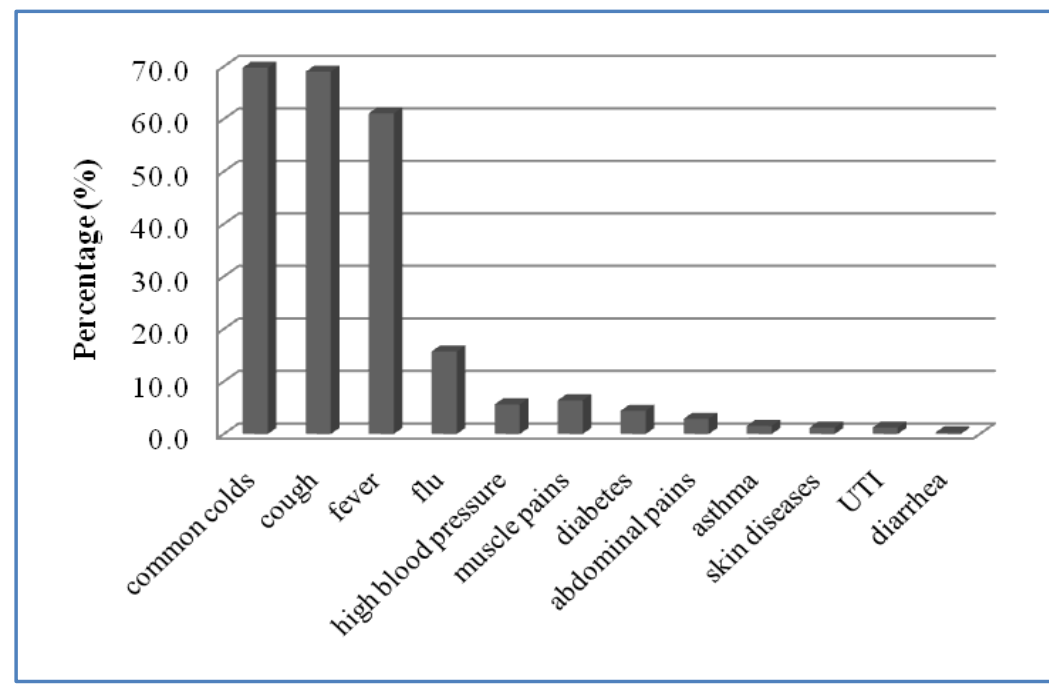

Figure 3 Over-all ailments associated with the use of CAM by the residents of upland Cavite. 
Table 5 Attitude towards CAM by the residents (in percent) of selected city and municipalities representing upland Cavite.

\begin{tabular}{|c|c|c|c|c|c|c|c|}
\hline \multirow[t]{2}{*}{ Attitude Towards CAM } & \multicolumn{6}{|c|}{ Municipalities/City } & \multirow[b]{2}{*}{ 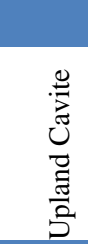 } \\
\hline & $\begin{array}{l}0 \\
\text { Oे } \\
\stackrel{0}{Z} \\
\end{array}$ & $\begin{array}{l}\stackrel{8}{8} \\
\mathbb{Z} \\
\mathbb{Z}\end{array}$ & 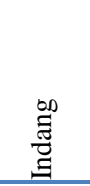 & 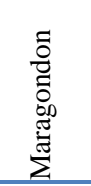 & $\frac{\tilde{d}}{\frac{N}{0}}$ & 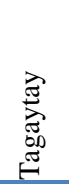 & \\
\hline Verv Strong & 18 & 6 & 0 & 12 & 10 & 0 & 8.2 \\
\hline Strong & 39 & 58 & 44 & 52 & 28 & 25 & 33.4 \\
\hline Fair & 33 & 13 & 56 & 34 & 56 & 87 & 57.6 \\
\hline Weak & 0 & 3 & 0 & 2 & 0 & 0 & 1.0 \\
\hline Verv Weak & 0 & 3 & 0 & 0 & 0 & 0 & 0.5 \\
\hline Over-all Scale & 3.94 & 3.74 & 3.56 & 3.74 & 3.51 & 3.22 & 3.62 \\
\hline Interpretation & Strong & Strong & Strong & Strong & Strong & Fair & Strong \\
\hline
\end{tabular}

Sicknesses which were less treated with the different forms of CAM in present study comprised of complicated diseases such as diabetes, hypertension, and kidney disorders. Use of CAM as therapies for these complicated ailments might be attributed to the patients' hope for total cure, this might be especially true since some of such illnesses notably diabetes and hypertension, are chronic in their nature (Table 3). In general different ailments treated by respondents with CAM in the present might be an indication of their extent of prevalent in the studied area.

It is quite interesting to note that all respondents were unanimous in their choice of top three diseases in which CAM is used. These are the three most common illnesses which normally are non-life threatening, whereas those illnesses which can be considered more serious such as heart problem and anemia seemed to have not been treated with CAM as shown in figure 3 .

\subsection{Attitude towards CAM}

Participants residing in the municipalities of Alfonso, Amadeo, Maragondon, and Mendez in upland Cavite responded positively on the use of CAM, having a mean range of 3.51 to 3.94 and with a descriptive interpretation of strong. This is to some extent is a reflection that the practice of CAM amongst the people inhabiting these areas is rooted in their culture, thus future studies similar to ours, should target such areas for rich data collection. However, the opposite of these can be said with regards to participants from the city of Tagaytay who rated the use of CAM as fair, with a mean rating of 3.22. Table 6 below summarizes the attitude of the respondents towards the use of CAM.

Table 5 shows that, generally respondents from upland Cavite strongly agreed on the use of CAM, with a mean rating of 3.62. This suggests that attitudes of the public regarding CAM therapies have remarkably become positive. Furthermore, is show that this type of therapies is becoming increasingly acceptable amongst general public in the areas studied. The strong attitude displayed by the respondents in the present study towards the use of CAM might be ascribed to the strong conviction of the efficacy of different forms of these therapies for preventive and treatment of some common ailments.

\section{Conclusions}

Leaf extract/decoction and traditional massage (hilot) emerged as the most common forms of complementary and alternative medicines used by the respondents. These therapies were both ranked first and second, respectively, in all municipalities/city representing upland Cavite. The present study further found that the questioned participants were mainly persuaded by their family members and doctors to utilise CAM.

The principal afflictions treated with CAM in upland Cavite encompassed common colds, cough, and fever. Overall, remedies used for treatment of these ailments were mainly prepared from herbal medicines. The four municipalities representing upland Cavite rated the use of CAM as strong while Tagaytay City rated it with fair. In general, survey revealed a positive attitude towards CAM among residents of the study sites with an over-all rating of 3.62 interpreted as strong.

\section{Conflict of interest}

Authors would hereby like to declare that there is no conflict of interests that could possibly arise.

\section{Acknowledgments}

The researchers would like to thank De La Salle UniversityDasmariñas through the University Research Office, for the funding of this research. Furthermore we are indebted to the residents of Tagaytay City and municipalities of Indang, Maragondon, Amadeo, Magallanes, and Alfonso for their willingness and cooperationduring data collection.

\section{References}

Arsenio JJ, Medecilo M, Mercado ET, Salibay ET Jr, Valera AH (2011) The Vegetation of Mt. Maculot, Cuenca Batangas, 
Philippines. International Journal of Environmental Science and Development 2: 274-278.

Bensoussan A, Myers SP, Wu SM, O'Connor K (2004) Naturopathic and Western herbal medicine practice in Australia: A workforce survey. Complementary Therapies in

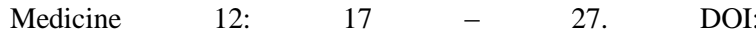
http://dx.doi.org/10.1016/j.ctim.2004.01.001

Erasto P, Majinda RRT (2011) Bioactive proanthocyanidins from the root bark of Cassia abbreviata. International Journal of Biological and Chemical Sciences 5(5): 2170-2179. doi: http://dx.doi.org/10.4314/ijbcs.v5i5.36

Erasto P, Adebola PO, Grierson DS, Afolayan AJ (2005) An ethnobotanical study of plants used for the treatment of diabetes in the Eastern Cape Province, South Africa. African Journal of Biotechnology 4:1458 - 1460.

Furnham A (2000) Attitudes towards homoeopathy in particular and beliefs about complementary medicines in general. Psychology, Health and Medicine 5: 327 - 342. DOI:10.1080/713690198.

Jadhav MP, Jadhav PM, Shelke P, Sharma Y, Nadkar M (2011) Assessment of use of complementary alternative medicine and its impact on quality of life in the patients attending rheumatology clinic in a tertiary care centre in India. Indian Journal of Medical Sciences 65: 50-57. DOI: 10.4103/0019-5359.103961.

Koh HL, Ng HL, Teo HH (2004) A survey of knowledge, attitudes and usage of complementary and alternative medicine in Singapore. Asia-Pacific Biotech News 8: 1266 - 1270. DOI: $10.1142 / \mathrm{S} 0219030304002162$.

Kuo GM, Hawley ST, Weiss LT, Balkrishnan R, Volk RJ (2004) Factors associated with herbal use among urban multiethnic primary care patients: A cross-sectional survey. BMC Complementary and Alternative Medicine 4:18. DOI: 10.1186/1472-6882-4-18.

Lee PY, Taha ABA, Lin K, Ghazali SR, Almashoor SHSA (2007) Usage of complementary and alternative medicine among primary care clinic attendees, Kuching, Sarawak, Malaysia, January - April 2004. Asia Pacific Journal of Family Medicine 6:1-6.

Marshik PL, Kharat AA, Jakeman B, Borrego ME, Dodd MA, Bachyrycz A, Anderson JR, Bond R, Deming P, Mercier R, Nawarskas JJ, Ray G, Salazar K (2016) Complementary and Alternative Medicine and Therapy Use in a Diverse New Mexican Population. Journal of Alternative \& Complementary Medicine22: 1, 45-51. DOI: 10.1089/acm.2014.0378.

Matheka DM, Demaio AR (2013) Complementary and alternative medicine use among diabetic patients in Africa: A
Kenyan perspective. Pan African Medical Journal 15. DOI: 10.11604/pamj.2013.15.110.2925.

Mc Farlane C (2015) South Africa: The Rise of Traditional Medicine. Insights on Africa 7: $60-70$. doi: 10.1177/0975087814554070

Roy V, Gupta M, Ghosh RK (2015) Perception, attitude and usage of complementary and alternative medicine among doctors and patients in a tertiary care hospital in India. Indian Journal of Pharmacology 47: 2, 137-142. DOI: 10.4103/02537613.153418

Salibay CC, Aoanan G, Aspra MET, Unabia T, Perrido E (2007) Tenured migrants' resource utilization of Mts. Palaypalay/MataasnaGulod National Park, Luzon Island, Philippines. Journal of Science and Technology 1: 62-72.

Salibay CC, Aoanan G, Aspra MET, Unabia T, Perrido E (2009) The socio-cultural practices and beliefs of the teunured migrants and their impact on Mts. Palaypalay/Mataasna Gulod forest resources. Journal of Science and Technology 3:34-46.

Shaikh SH, Malik F, James H, Abdul H (2008) Trends in the use of complementary and alternative medicine in Pakistan: a population-based survey. Journal of Alternative and Complementary Medicine15: 545 - 550. doi: 10.1089/acm.2008.0232.

Silvanathan S, Low BS (2015) Current public awareness on the safety of traditional and complementary medicines in Malaysia. European Journal of Integrative Medicine 7 :184189. DOI: 10.1016/j.eujim.2014.12.003

Singh V, Raidoo DM, Harries CS (2004) The prevalence, patterns of usage and people's attitude towards complementary and alternative medicine (CAM) among Indian community in Chatsworth, South Africa. BMC Complementary and Alternative Medicine 4:1-7. DOI: 10.1186/1472-6882-4-3.

Sivadasan S, Ali AN, Lin LW, Balakrishnan D, Ramachandran S, Dhanaraj SA (2014) Use of complementary and alternative medicine in the population of Kedah Darul Aman, Malaysia. International Journal of Pharmaceutical Sciences and Research 5:4, 1263 - 1273. DOI: 10.13040/IJPSR.0975-8232.5(4).126363

Stange R, Amhof R, Moebus S (2008) Complementary and alternative medicine: Attitudes and patterns of use by German physicians in a national survey. Journal of Alternative and Complementary Medicine 14: 1255-1251. doi: 10.1089/acm.2008.0306

Valenzuela-Antelo O, Garibay-Escobar A, VelázquezContreras C, Navarro-Navarro M, Contreras LR, Corral OL, Lozano-Taylor J (2011) Use of Complementary and Alternative Medicine in a Region of Northwest Mexico. 
Journal of Alternative \& Complementary Medicine 17: 787 -

788. DOI: $10.1089 / \mathrm{acm} .2011 .0234$

Wolf U, Maxion-Bergemann S, Bornhoft G, Matthiessen PF, Wolf M (2006) Use of complementary medicine in Switzerland. Forsch Komplementarmed 13:S4-S6.
Xue CL, Zhang AL, Lin V, Da Costa C, Story DF (2007) Complementary and alternative medicine use in Australia: A national population-based survey. The Journal of Alternative and Complementary Medicine 13: 643 - 650. doi:10.1089/acm.2006.6355.

Appendix 1. Herbal plants used by residents of upland Cavite to treat common ailments.

\begin{tabular}{|c|c|c|c|c|}
\hline Botanical Family & Scientific name & Common name & Part/s used & $\begin{array}{l}\text { Method of } \\
\text { Preparation }\end{array}$ \\
\hline \multicolumn{5}{|l|}{ Fever } \\
\hline Annonaceae & Annona muricata $\mathrm{L}$. & Guyabano & Leaves & Decoction \\
\hline Asteracee & Artemisia vulgaris $\mathrm{L}$. & Maria & Leaves & Decoction \\
\hline \multirow[t]{2}{*}{ Fabacecae } & \multirow[t]{2}{*}{ Tamarindus indica $\mathrm{L}$. } & \multirow[t]{2}{*}{ Sampalok } & Fruits & Eaten \\
\hline & & & Leaves/stems & Bath \\
\hline Lythraceae & Lagerstroemia speciosa (L.) Pers. & Banaba & Leaves & Poultice \\
\hline Orchidaceae & Grammatophyllum scriptum L. Blume. & Tawa-tawa & Leaves & Decoction \\
\hline Oxalidaceae & Averrhoa carambola $\mathrm{L}$. & Balimbing & Leaves & Decoction \\
\hline Verbenaceae & Vitex negundo L. & Lagundi & Leaves & Decoction \\
\hline \multicolumn{5}{|l|}{ Common colds } \\
\hline Asteraceae & Blumea balsamifera (L.) DC. & Sambong & Leaves & Decoction \\
\hline Moringaceae & Moringa oleifera Lam. & Malunggay & Leaves & Extraction \\
\hline Orchidaceae & Grammatophyllum scriptum L. Blume. & Tawa-tawa & Leaves & Decoction \\
\hline Phyllantaceae & Phyllantrus niruri $\mathrm{L}$. & Sampa-sampalukan & Leaves & Decoction \\
\hline \multicolumn{5}{|l|}{ Cough and flu } \\
\hline \multirow[t]{2}{*}{ Asteraceae } & Artemisia vulgaris $\mathrm{L}$. & Maria & Leaves & Decoction \\
\hline & Blumea balsamifera (L.) DC. & Sambong & Leaves & Decoction \\
\hline Annonaceae & Annona muricata $\mathrm{L}$. & Guyabano & Leaves & Decoction \\
\hline Bignoniaceae & $\begin{array}{l}\text { Tabebuia avellanedae Lorentz ex } \\
\text { Griseb. }\end{array}$ & Taheebo & Leaves & Decoction \\
\hline Crassulaceae & Bryophyllum pinnatum (Lam.) Oken. & Kataka-taka & Leaves & Decoction \\
\hline Fabaceae & $\begin{array}{llll}\text { Gliricidia sepium (Jacq.) Kunth ex } \\
\text { Steud. }\end{array}$ & Kakawati/ malabe & Leaves/fruits & Decoction \\
\hline Euphorbiaceae & Croton tigilium L. Gasi. (Sul.) & Tuba & Leaves & Decoction \\
\hline Lamiaceae & Origanum vulgare $\mathrm{L}$. & Oregano & Leaves & Decoction \\
\hline Lythraceae & Lagerstroemia speciosa (L.) Pers. & Banaba & Leaves & Decoction \\
\hline Mackinlayaceae & Centella asiatica (L.) Urb. & Takip-suso & Leaves & Decoction \\
\hline Orchidaceae & Grammatophyllum scriptum L. Blume. & Tawa-tawa & Leaves & Decoction \\
\hline Piperaceae & Piper betle $\mathrm{L}$. & Ikmo & Leaves & Poultice \\
\hline \multirow[t]{3}{*}{ Rutaceae } & \multirow[t]{3}{*}{ Citrus microcarpa Bunge. } & \multirow{2}{*}{$\begin{array}{l}\text { Kalamansi/ } \\
\text { Kalumunding }\end{array}$} & Leaves & Decoction \\
\hline & & & Fruit & Eaten \\
\hline & & Klaba & Leaves & Extraction \\
\hline Verbenaceae & Vitexnegundo L. & Lagundi & Leaves & Decoction \\
\hline
\end{tabular}




\begin{tabular}{|c|c|c|c|c|}
\hline \multicolumn{5}{|l|}{ Wound } \\
\hline Myrtaceae & Psidium guajava $\mathrm{L}$. & Bayabas & Leaves & $\begin{array}{l}\text { Washing } \\
\text { antiseptic }\end{array}$ \\
\hline Solanaceae & $\begin{array}{l}\text { Polanisia iconsandra (L.) Wight and } \\
\text { Arn. }\end{array}$ & Sili-silihan & Leaves & Poultice \\
\hline \multirow[t]{2}{*}{ Fabaceae } & Cassia alata $\mathrm{L}$. & Akapulko & Leaves & Extraction \\
\hline & Mimosa pudica $\mathrm{L}$. & Makahiya & Leaves & Poultice \\
\hline \multicolumn{5}{|c|}{ Urinary tract infection (UTI) } \\
\hline Asteraceae & Blumea balsamifera (L.) DC. & Sambong & Leaves & Decoction \\
\hline Annonaceae & Annona muricata $\mathrm{L}$. & Guyabano & Leaves & Decoction \\
\hline Fabaceae & Cassia alata $\mathrm{L}$. & Akapulko & Leaves & Decoction \\
\hline \multirow[t]{2}{*}{ Lythraceae } & Lagerstroemia speciosa (L.) Pers. & Banaba & Leaves & Decoction \\
\hline & & & Stems & Decoction \\
\hline \multirow[t]{2}{*}{ Poaceae } & Imperata cylindrica (L.) Beauv. & Kogon & Roots & Decoction \\
\hline & Zea mays L. & Corn/mais & Silk & Decoction \\
\hline Lamiaceae & Orthosiph onaristatus (Blume) Miq. & Balbaspusa & Leaves & Decoction \\
\hline Piperaceae & Pepperomia pellucida $\mathrm{L}$. & Pansit-pansitan & Leaves & Eaten as raw \\
\hline
\end{tabular}

